\title{
PANCURONIUM FOR RAPID INDUCTION TECHNIQUE FOR TRACHEAL INTUBATION
}

\author{
Ely M. Brown, Deepika Krishnaprasad and Barky G. Smiler
}

\begin{abstract}
A PATIENT with a full stomach who requires anaesthesia for an emergency opcration or an obstetrical procedure is frequently managed by a rapid induction (crash) technique. This technique ordinarily includes the use of suxamethonium to provide relaxation of the jaw so that tracheal intubation can be accomplished quickly. There are a number of conditions, however, that contraindicate the use of suxamethonium. These conditions include genetic abnormalities, central nervous system lesions that result in muscle atrophy, and severe burns.' Moreover, succinylcholine is not desirable when it is essential to avoid an increase in intraocular pressure or intractanial pressure. ${ }^{2}$ Under these circumstances, it would be preferable to use a non-depolarizing muscle relaxant for the rapid induction technique. The purpose of this study was to determine whether there is a dose of pancuronium that will produce adequate conditions for intubation fast enough to satisfy the purposes of a rapid intubation technique.
\end{abstract}

\section{Methods}

The study group consisted of $\mathbf{4 0}$ patients, 24 to 83 years of age. There were 14 males and 26 females. The total number of patients was divided into four groups of ten.

Premedication varied according to the patient's age, physical status, degree of anxiety, presence or absence of pain and the likelihood of increased secretions or reflex activity. In some instances premedication was omitted, in others it was solely an anticholinergic drug or a tranquillizer.

After appropriate premedication, the patients were pre-oxygenated and placed in the head-up position. Anaesthesia was induced with thiopentone 3 to $4 \mathrm{mg} \cdot \mathrm{kg}^{-1}$ or diazepam $20-40 \mathrm{mg}$,

Eli Brown. M.D., Professor and Chairman, Department of Anesthesiology, Wayne State University School of Medicine: Chairman, Department of Anesthesiology. Sinai Hospital of Detroit: Deepika Krishnaprasad, M.D., Resident, Department of Anesthesiology, Sinai Hospital of Detroit; Barry G. Smiler, M.D. Attending Staff, Department of Anesthesiology, Sinai Hospital of Detroit; 6767 West Outer Drive. Detroit. Michigan 48235, U.S.A. depending upon the condition of the patient. When the patient lost consciousness. cither suxamethonium $2 \mathrm{mg} \cdot \mathrm{kg}^{-1}$, pancuronium 0.1 $\mathrm{mg} \cdot \mathrm{kg}^{-1}$. pancuronium $0.15 \mathrm{mg} \cdot \mathrm{kg}^{-1}$, or pancuronium $0.2 \mathrm{mg} \cdot \mathrm{kg}^{-1}$ was administered. Dtubocurarine $3 \mathrm{mg}$ was administered four to five minutes before suxamethonium.

Blood pressure, heart rate, temperature, electrocardiogram and twitch response were recorded throughout the study period. Twitch response was monitored by stimulating the ulnar nerve at the elbow every five seconds by subcutaneous needle electrodes from a BurroughsWellcome Block-Aid Monitor. An FTlOC transducer was used to record the response on a Hewlett-Packard \#702B Recorder. Control readings were obtained immediately after induction of anaesthesia and before administration of the test drugs. Intubation of the trachea was not attempted until the recorder demonstrated 90 per cent or more depression of control twitch. All the intubations were done by the same anaesthetist. The degree of vocal cord relaxation was evaluated by the anaesthetist according to the criteria of Lund and Stovner ${ }^{3}$ (Table I).

\section{RESULTS}

The time in seconds from the administration of the relaxant drug to 90 per cent twitch depression for each group is recorded in Table II. The degree of vocal cord relaxation is recorded in Table III. The data were tested for significance by means of the Student $t-T e s t$. There was no significant difference between suxamethonium and pancuronium $0.2 \mathrm{mg} \cdot \mathrm{kg}^{-1}$ nor between suxamethonium and pancuronium $0.15 \mathrm{mg} \cdot \mathrm{kg}^{-1}$ with regard to time to 90 per cent twitch depression. Pancuronium $0.1 \mathrm{mg} \cdot \mathrm{kg}^{-1}$, however, took a significantly longer time to produce 90 per cent twitch depression $(p<0.05)$.

\section{Discussion}

Although suxamethonium is ordinarily the drug of choice for a rapid induction technique of anaesthesia, there are situations where a nondepolarizing muscle relaxant drug is preferable.

Canad. Anaesth. Soc. J., vol. 26, no. 6, November 1979 
TABLE I

Criteria for Yocal Cord Relaxation

\begin{tabular}{ll}
\hline Excellent & Vocal cords totally paralyzed, no bucking \\
Satisfactory & Slight bucking \\
Fair & Vigorous coughing and bucking \\
Poor & Unable to intubate \\
\hline
\end{tabular}

TABLE II

\begin{tabular}{lcccc}
\hline & $\begin{array}{c}\text { D-Tubocurare } \mathbf{3} \mathrm{mg} \\
\text { followed by } \\
\text { suxamethonium }\end{array}$ & $\begin{array}{c}\text { Pancuronium } \\
0.2 \mathrm{mg} \cdot \mathbf{k g}^{-1}\end{array}$ & $\begin{array}{c}\text { Pancuronium } \\
0.15 \mathrm{mg} \cdot \mathbf{k g}^{-1}\end{array}$ & $\begin{array}{c}\text { Pancuronium } \\
\mathbf{0 . 2} \mathbf{m g} \cdot \mathbf{k g}^{-1}\end{array}$ \\
\hline $\begin{array}{l}\text { No. of patients } \\
\begin{array}{l}\text { Time to } 90 \% \\
\text { Twitch depression } \\
\text { (seconds) }\end{array}\end{array}$ & 10 & 10 & 10 & 10 \\
$\begin{array}{l}\text { Standard deviation } \\
\text { Significant difference }\end{array}$ & 72 & 175 & 75 & 60 \\
\hline
\end{tabular}

*Significantly longer than other three groups.

TABLE III

Degree of Vocal Cord Relaxation

\begin{tabular}{lcccc}
\hline \hline & $\begin{array}{c}\text { D-Tubocurare } \mathbf{3} \mathbf{~ m g} \\
\text { suxamethonium 2 } \mathbf{m g} \cdot \mathbf{k g}^{-1}\end{array}$ & $\begin{array}{c}\text { Pancuronium } \\
0.1 \mathrm{mg} \cdot \mathbf{k g}^{-1}\end{array}$ & $\begin{array}{c}\text { Pancuronium } \\
\mathbf{0 . 1 5} \mathbf{m g} \cdot \mathbf{k g}^{-1}\end{array}$ & $\begin{array}{c}\text { Pancuronium } \\
\mathbf{0 . 2} \mathbf{m g} \cdot \mathbf{k g}^{-1}\end{array}$ \\
\hline Excellent & 10 & 8 & 10 & 10 \\
Satisfactory & 0 & 2 & 0 & 0 \\
Fair & 0 & 0 & 0 & 0 \\
Poor & 0 & 0 & 0 & 0 \\
\hline
\end{tabular}

The most obvious is the patient who requires an emergency operation for laceration of the cornea. In this case, a rise in intraocular pressure could result in loss of the eye. The pathologic conditions that cause muscle atrophy mentioned previously certainly require the use of a nondepolarizing relaxant.

Chatterjee, et $a l^{4}$ studied the use of pancuronium for intubation prior to emergency oper. ations in 32 patients. These authors state that pancuronium in a dose of $0.1 \mathrm{mg} \cdot \mathrm{kg}^{-1}$ was found to be "satisfactory for quick intubation" . They did not report the time lag between the injection of pancuronium and laryngoscopy, nor did they indicate that the degree of muscle relaxation was monitored. Conversely, Barr and Thornleys found pancuronium $0.1 \mathrm{mg} \cdot \mathrm{kg}^{-1}$ to be inferior to suxamethonium in terms of time to intubation, activity of vocal cords and response to stimuli during induction. Our results indicate that pancuronium in a dose of $0.1 \mathrm{mg} \cdot \mathrm{kg}^{-1}$, is not as reliable as suxamethonium for rapid tracheal intubation. If the dose is increased to $0.15 \mathrm{mg} \cdot \mathrm{kg}^{-1}$, however, pancuronium provides adequate conditions for intubation in about the same time and as consistently as suxamethonium. Since completion of this study, we have used pancuronium $0.15 \mathrm{mg} \cdot \mathrm{kg}^{-1}$ for rapid tracheal intubation in 18 additional patients. So far, we have encountered no difficulty.

Tachycardia and hypertension following pancuronium described by Kelman and Kennedy* and by Loh' has not been a problem in our tech. nique of balanced anaesthesia. Fentanyl is administered in sufficient amounts $(0.1 \mathrm{mg}-0.3$ $\mathrm{mg}$ ) to effectively block any increase in heart rate or blood pressure that might occur during induction of anaesthesia and immediately following tracheal intubation. In our study, only two patients in the pancuronium group developed a heart rate more than 20 per cent above control value. This rise was promptly reversed by the addition of fentany $10.1 \mathrm{mg}$ in one patient and 0.15 $\mathrm{mg}$ in the second patient.

A disadvantage of the use of large doses of pancuronium is seen in the occasional patient 
who must be kept on a ventilator following operation. In our study eight patients needed ventilatory support postoperatively. Seven of the patients who required ventilatory support had received pancuronium $0.2 \mathrm{mg} \cdot \mathrm{kg}^{-1}$. Since this dose seems unnecessarily large, we recommend pancuronium $0.15 \mathrm{mg} \cdot \mathrm{kg}^{-1}$ for rapid tracheal intubation when the use of suxamethonium is either contraindicated or undesirable.

\section{Summary}

Suxamethonium in a dose of $2 \mathrm{mg} \cdot \mathrm{kg}^{-1}$ was compared to pancuronium in three different dosages $\left(0.1 \mathrm{mg} \cdot \mathrm{kg}^{-1}, 0.15 \mathrm{mg} \cdot \mathrm{kg}^{-1}, 0.2 \mathrm{mg} \cdot \mathrm{kg}^{-1}\right)$ for a rapid induction (crash) technique for tracheal intubation. Pancuronium $0.1 \mathrm{mg} \cdot \mathrm{kg}^{-1}$ was inferior to suxamethonium, but the larger doses of pancuronium were equally satisfactory. In those instances where suxamethonium is either contraindicated or undesirable, pancuronium in a dose of $0.15 \mathrm{mg} \cdot \mathrm{kg}^{-1}$ is a suitable alternative for rapid induction for tracheal intubation.

\section{RÉSUMÉ}

Nous avons comparé le pancuronium à la dose de $0.1,0.15$ et $2 \mathrm{mg} \cdot \mathrm{kg}^{-1}$, à la succinylcholine à la dose de $2 \mathrm{mg} \cdot \mathrm{kg}^{-1}$, lorsque ces agents sont utilisés pour intubation rapide lors de l'induction de l'anesthésie. Le pancuronium à la dose de $0.1 \mathrm{mg} \cdot \mathrm{kg}^{-1}$ s'est avéré inférieur à la succinylcholine, mais aux doses de 0.15 et de 0.2 $\mathrm{mg} \cdot \mathrm{kg}^{-1}$, il s'est avéré entièrement satisfaisant. Dans les cas où l'emploi de la succinylcholine est contre-indiqué ou indésirable, le pancuronium, à raison de $0.15 \mathrm{mg} \cdot \mathrm{kg}^{-1}$ représente une alternative valable lorsqu'il est nécessaire de procéder à une intubation rapide.

\section{REFERENCES}

1. Walts, L.F. Complications of muscle relaxants. Muscle Relaxants, Ist ed, p. 209. Amsterdam: Excerpta Medica (1975).

2. Halldin, M. \& Wahlin. A. Effect of succinylcholine on the intraspinal fluid pressure. Acta Anaesthesiol. Scand. 3: 155 (1959).

3. Lund, 1. \& Stovner, J. Dose-response curves for tubocurarine, alcuronium and pancuronium. Acta Anaesthesiol. Scand. Suppl. 37: 238 (1970).

4. Chatteruee, S.C., Chatteruee, S.K. \& BhatTaCHarrya, D. Pancuronium bromide in emergency surgery. Anaesthesia $31: 694$ (1976).

5. BAR. A.M. \& ThORNLEY. B.A. Thiopentone and pancuronium crash induction. Anaesthesia 33:25 (1978).

6. Kelman, G.R. \& Kennedy, B.R. Cardiovascular effects of pancuronium in man. Br, J. Anaesth, 43; 335 (1971).

7. LoH, L. The cardiovascular effects of pancuronium bromide. Anaesthesia 25: 356 (1970). 